PREPARED FOR THE U.S. DEPARTMENT OF ENERGY, UNDER CONTRACT DE-AC02-76CH03073

PPPL-3687

PPPL-3687

UC-70

Ion-beam Plasma Neutralization Interaction Images

by

Igor D. Kaganovich, Edward Startsev,

S. Klasky and Ronald C. Davidson

April 2002

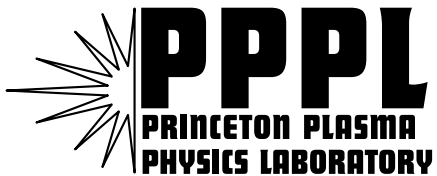

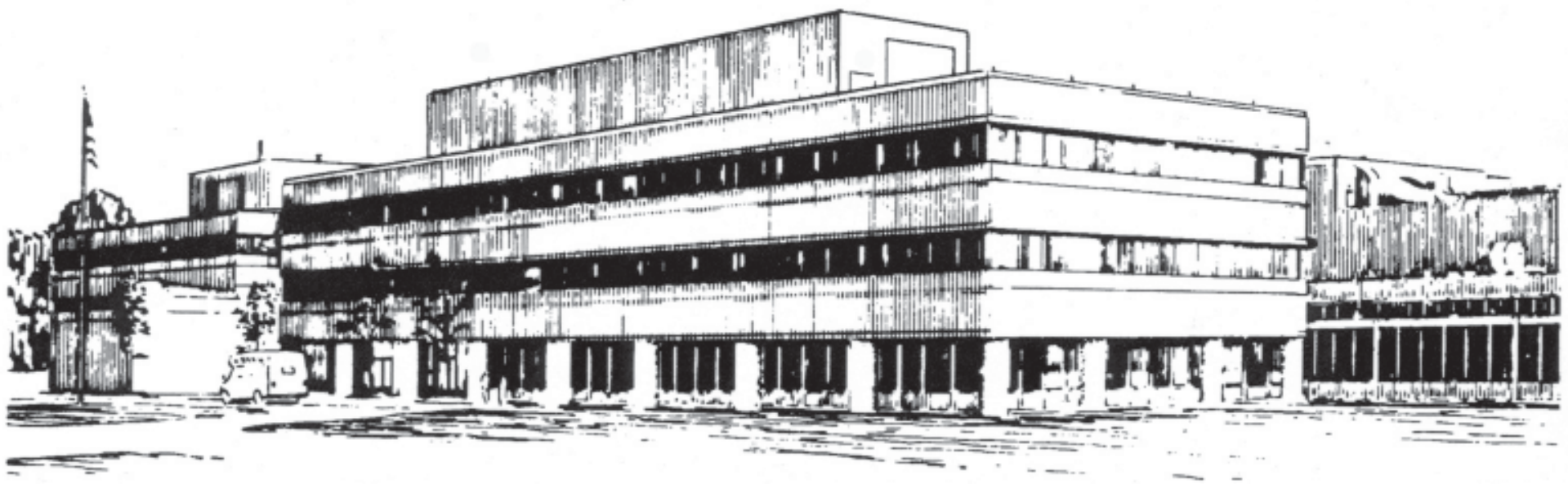

PRINCETON PLASMA PHYSICS LABORATORY PRINCETON UNIVERSITY, PRINCETON, NEW JERSEY 


\section{PPPL Reports Disclaimer}

This report was prepared as an account of work sponsored by an agency of the United States Government. Neither the United States Government nor any agency thereof, nor any of their employees, makes any warranty, express or implied, or assumes any legal liability or responsibility for the accuracy, completeness, or usefulness of any information, apparatus, product, or process disclosed, or represents that its use would not infringe privately owned rights. Reference herein to any specific commercial product, process, or service by trade name, trademark, manufacturer, or otherwise, does not necessarily constitute or imply its endorsement, recommendation, or favoring by the United States Government or any agency thereof. The views and opinions of authors expressed herein do not necessarily state or reflect those of the United States Government or any agency thereof.

\section{Availability}

This report is posted on the U.S. Department of Energy's Princeton Plasma Physics Laboratory Publications and Reports web site in Fiscal Year 2002. The home page for PPPL Reports and Publications is: http://www.pppl.gov/pub_report/

DOE and DOE Contractors can obtain copies of this report from:

U.S. Department of Energy

Office of Scientific and Technical Information

DOE Technical Information Services (DTIS)

P.O. Box 62

Oak Ridge, TN 37831

Telephone: (865) 576-8401

Fax: (865) 576-5728

Email: reports@adonis.osti.gov

This report is available to the general public from:

National Technical Information Service

U.S. Department of Commerce

5285 Port Royal Road

Springfield, VA 22161

Telephone: 1-800-553-6847 or

(703) 605-6000

Fax: (703) 321-8547

Internet: http://www.ntis.gov/ordering.htm 


\title{
Ion-Beam Plasma Neutralization Interaction Images
}

\author{
Igor D. Kaganovich, Edward Startsev, S. Klasky, and Ronald C. Davidson, \\ Plasma Physics Laboratory, Princeton University, Princeton, NJ 08543, USA
}

Abstract - Neutralization of the ion beam charge and current is an important scientific issue for many practical applications. The process of ion beam charge and current neutralization is complex because the excitation of nonlinear plasma waves may occur. Computer simulation images of plasma neutralization of the ion beam pulse are presented. 
The propagation of a high-current finite-length ion beam in a background plasma is of considerable interest for many applications, including heavy ion fusion, plasma lenses, cosmic ray propagation, etc. Many applications rely on the neutralized transport of positively charged particles. Heavy ion fusion considers the ballistic focusing of stripped heavy ions. High-energy physics applications involve the transport of intense positron beams. In these applications, the plasma is pre-formed by an external source and is independent of the beam characteristics.

A suite of simulation codes has been developed to calculate the degree of charge and current neutralization of an ion beam pulse by the background plasma. The suite consists of two different codes: a fully electromagnetic, relativistic, particle-in-cell (PIC) code, and a nonrelativistic, Darwin fluid model for long beam pulses $[1,2]$.

In this paper, we present images generated from this suite of codes; the visualization has been performed using the AVS/Express software [3]. Figure 1 shows the steady-state propagation of the beam through a cold background plasma with uniform density $n_{p}$. The electrons, attracted by the beam ions, move to neutralize the beam charge on a time scale $1 / \omega_{p}$, where $\omega_{p}=\left(4 \pi e^{2} n_{p} / m\right)^{1 / 2}$ is the electron plasma frequency. Therefore, if the beam half length $\left(l_{b}\right)$ is small compared with the neutralization length $V_{b} / \omega_{p}\left(V_{b}\right.$ is the beam velocity), the electrons do not neutralize the beam charge [Fig.1(a)]. For long beams, however, the charge neutralization is nearly complete, but large-amplitude plasma waves are excited by the beam front [Fig.1(d) and 1(e)]. Figures 1(a)-1(d) were generated using a fluid model, whereas the data in Fig.1(e) were obtained from a particle-in-cell code. The trajectory of electron fluid elements intersect at one point in Fig.1(e), thus producing a singularity in the fluid solution. Therefore, at sufficiently large beam densities plasma waves cannot be described by a one-fluid approximation. 
Nonlinear plasma waves are rather complex phenomena, and the images in Figs.1(d) and 1(e) resemble one of the primitive biological organisms called 'trilobites' [4]. The similar study has been done by Mission Research Corp. [5].

In conclusion, computer simulation images of beam-plasma interactions have been presented. These images provide important information on the complex physical processes occurring during beam propagation.

Acknowledgment: This research was supported by the U.S. Department of Energy.

\section{REFERENCES}

[1] I. D. Kaganovich, G. Shvets, E. Startsev and R. C. Davidson, Physics of Plasmas 8, 4180 (2001).

[2] I. D. Kaganovich, G. Shvets, E. Startsev and R. C. Davidson, Proc. 2001 Particle Accelerator Conference; http://pacwebserver.fnal.gov/papers/Tuesday/PM Poster/TPPH317.pdf

[3] http://www.avs.com/software/soft_t/avsxps.html

[4] http://www.trilobites.com

[5] http://www.mrcabq.com/Services/Particle/Codes/codes.htm

\section{Figure captions}

Fig.1 Neutralization of an ion beam pulse during steady-state propagation of the beam pulse through a cold, uniform, background plasma. The beam propagates along the y-axis. The beam density has a flattop profile, and the red lines show the beam pulse edges. Shown in the figure are contour plots of the normalized electron density $\left(n_{e} / n_{p}\right)$ and the normalized longitudinal current $\left(j_{z} / e n_{p} c\right)$ in $\left(x \omega_{p} / c, y \omega_{p} / c\right)$ space. The brown contours show the electron trajectories in the beam frame. The beam velocity is $V_{b}=0.5 c$, and the beam density is $n_{b}=0.5 n_{p}$ for Figs.1(a)-1(d), and $n_{b}=n_{p}$ for Fig.1(e). 
The beam dimensions correspond to (a) $r_{b}=0.03 c / \omega_{p}, l_{b}=0.3 c / \omega_{p}$, (b) $r_{b}=0.1 c / \omega_{p}, l_{b}=1.0 c / \omega_{p}$, (c) $r_{b}=0.3 c / \omega_{p}, l_{b}=3.0 c / \omega_{p}$, (d) $r_{b}=1.0 c / \omega_{p}, l_{b}=10 c / \omega_{p}$, and (e) $r_{b}=1.5 c / \omega_{p}, l_{b}=15 c / \omega_{p}$. 

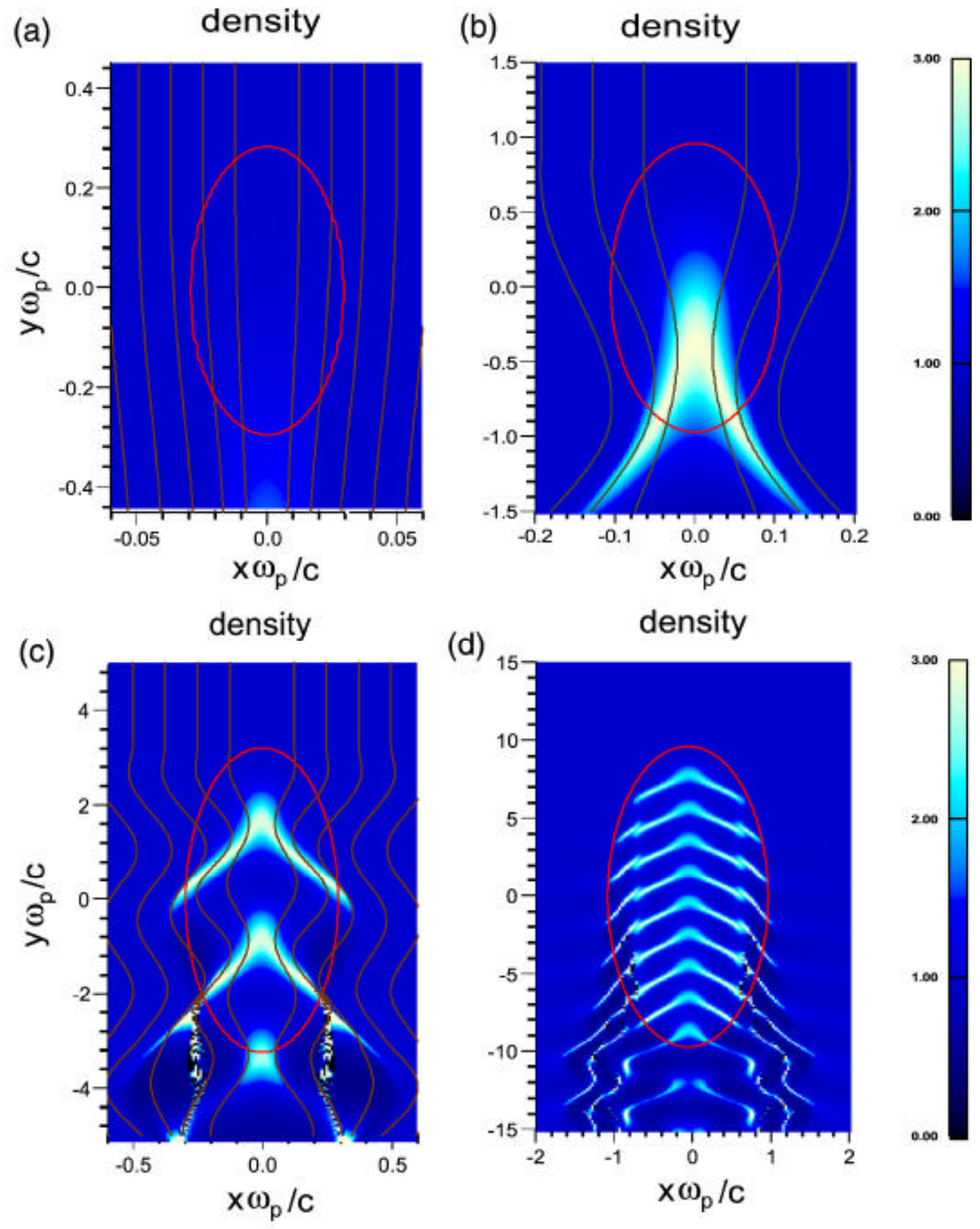

(d)
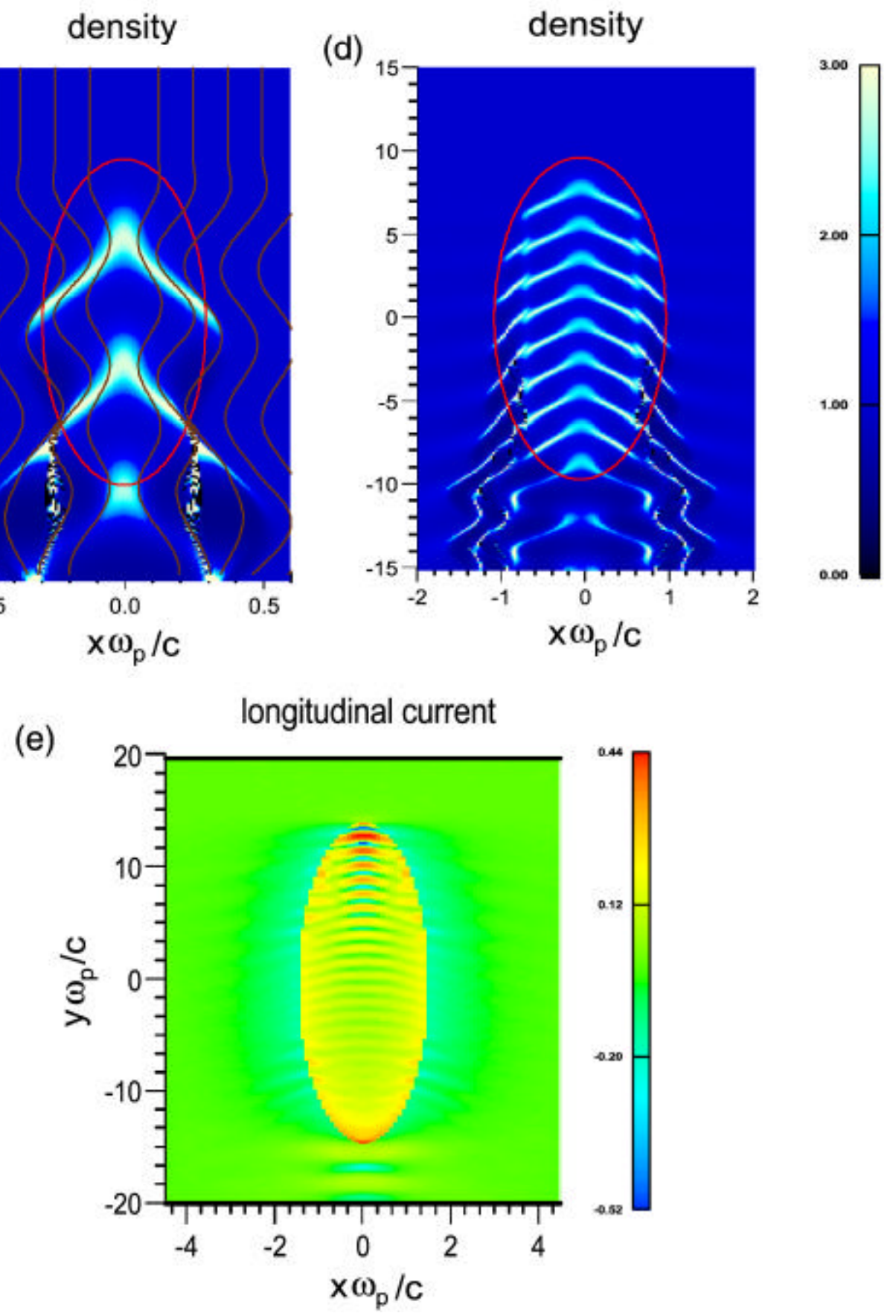


\section{External Distribution}

Plasma Research Laboratory, Australian National University, Australia

Professor I.R. J ones, Flinders University, Australia

Professor J oão Canalle, Instituto de Fisica DEQ/IF - UERJ , Brazil

Mr. Gerson O. Ludwig, Instituto Nacional de Pesquisas, Brazil

Dr. P.H. Sakanaka, Instituto Fisica, Brazil

The Librarian, Culham Laboratory, England

Library, R61, Rutherford Appleton Laboratory, England

Mrs. S.A. Hutchinson, JET Library, England

Professor M.N. Bussac, Ecole Polytechnique, France

Librarian, Max-Planck-Institut für Plasmaphysik, Germany

J olan Moldvai, Reports Library, MTA KFKI-ATKI, Hungary

Dr. P. Kaw, Institute for Plasma Research, India

Ms. P.J . Pathak, Librarian, Insitute for Plasma Research, India

Ms. Clelia De Palo, Associazione EURATOM-ENEA, I taly

Dr. G. Grosso, Instituto di Fisica del Plasma, Italy

Librarian, Naka Fusion Research Establishment, J AERI, J apan

Library, Plasma Physics Laboratory, Kyoto University, J apan

Research Information Center, National Institute for Fusion Science, J apan

Dr. O. Mitarai, Kyushu Tokai University, J apan

Library, Academia Sinica, Institute of Plasma Physics, People's Republic of China

Shih-Tung Tsai, Institute of Physics, Chinese Academy of Sciences, People's Republic of China

Dr. S. Mirnov, TRINITI, Troitsk, Russian Federation, Russia

Dr. V.S. Strelkov, Kurchatov Institute, Russian Federation, Russia

Professor Peter Lukac, Katedra Fyziky Plazmy MFF UK, Mlynska dolina F-2, Komenskeho Univerzita, SK-842 15 Bratislava, Slovakia

Dr. G.S. Lee, Korea Basic Science Institute, South Korea

Mr. Dennis Bruggink, Fusion Library, University of Wisconsin, USA

Institute for Plasma Research, University of Maryland, USA

Librarian, Fusion Energy Division, Oak Ridge National Laboratory, USA

Librarian, Institute of Fusion Studies, University of Texas, USA

Librarian, Magnetic Fusion Program, Lawrence Livermore National Laboratory, USA

Library, General Atomics, USA

Plasma Physics Group, Fusion Energy Research Program, University of California at San Diego, USA

Plasma Physics Library, Columbia University, USA

Alkesh Punjabi, Center for Fusion Research and Training, Hampton University, USA

Dr. W.M. Stacey, Fusion Research Center, Georgia Institute of Technology, USA

Dr. J ohn Willis, U.S. Department of Energy, Office of Fusion Energy Sciences, USA

Mr. Paul H. Wright, Indianapolis, Indiana, USA 
The Princeton Plasma Physics Laboratory is operated by Princeton University under contract with the U.S. Department of Energy.

\author{
Information Services \\ Princeton Plasma Physics Laboratory \\ P.O. Box 451 \\ Princeton, NJ 08543
}

Phone: 609-243-2750

Fax: 609-243-2751

e-mail: pppl_info@pppl.gov

Internet Address: http://www.pppl.gov 